ANNALS, $A A P S S$, 479, May 1985

\title{
Problems and Paradoxes in Economic and Social Policies of Modern Welfare States
}

\author{
By W. ALLEN SPIVEY
}

\begin{abstract}
Relationships between economic growth rates and the expansion of welfare expenditures in Western nations are examined. The point is made that real gross national product grew rapidly from about 1959 until about 1973 , but that since 1973 it has either grown slowly or not at all, while welfare expenditures and entitlements have continued to escalate. Forecasts of a variety of important economic variables in these countries for the near term are presented and discussed, and it is concluded that despite the current modest economic improvement, difficulties in funding welfare states will continue throughout the remainder of the $1980 \mathrm{~s}$. Some consideration is given to problems in welfare states to the end of the century, and further difficulties in funding and managing these states are forecast for this period as well. Problems of welfare states are not regarded as short-term by-products of maladjustments experienced in the Western world in the last 10 years but rather as long-term characteristics.
\end{abstract}

W. Allen Spivey is C. E. Griffin Distinguished Professor of Business Administration and professor of statistics at the Graduate School of Business, University of Michigan. He holds the degrees of A.B., M.A., and Ph.D. from the University of North Carolina and did postdoctoral study at Stanford University. He has been visiting professor at Harvard University and the London School of Economics and a Fulbright professor at Kyoto and Doshisha Universities in Japan. His major research interest is in time series analysis and economic forecasting. 
$\mathrm{W}^{\mathrm{B}}$ ELFARE states in the Western world, though some have roots extending back over 100 years, began to grow rapidly only after the end of the post-World War II reconstruction period. Accelerations in the growth of these states took place in a context of sustained high levels of real economic growth, particularly between 1959 and 1973. It is often argued that much of the expansion in state welfare and in the redistribution of income, which by the 1960 s had become an essential feature of welfare states-indeed their central purpose in the view of many-came about largely because of the surpluses provided by these high rates of real economic growth.

Since the oil and commodity crises of 1973-74, however, annual real economic growth rates not only declined sharply, but became negative by the end of the 1970 s in many Western as well as nonWestern nations. With a smaller surplus, or perhaps none at all, yet with redistribution continuing to grow because of the momentum created by the earlier high rates of real economic growth and the continuing expansion of social legislation and entitlements, middle- and high-income persons became much more aware that resources were being allocated away from them and began to take actions to offset some of the effects of this loss. Unemployment levels also rose, leading to increases in government spending on income maintenance and on measures to reduce unemployment. Inflation rates mounted to high levels and afflicted virtually all Western economies, reducing the real value of social security funds, further eroding real incomes of some groups, and causing problems for the poor as well. Economists, accustomed to debating the so-called trade-off between unemployment and inflation, now looked with dismay upon economic systems in which both were rising to high levels. To put it briefly, we moved in the 1970s from a world of high expansion with low inflation to a world with low expansion and high inflation.

By the early years of the 1980s virtually every country in Western Europe had significant public sector deficits. Total government budgets were also in deficit in the United States, France, the United Kingdom, Belgium, the Netherlands, Sweden, and others. Even the strong growth economies of West Germany and Japan were experiencing budget deficits as well as current account deficits in their international trade-West Germany for the first time since 1953. One began to hear talk of the "crisis in the welfare state," and although this seems to be an overly colorful phrase because no Western nation has yet begun to dismantle or significantly to reduce its welfare state apparatus, rates of increase in welfare budgets have been moderated in many countries.

There also appears to be widespread belief that a more conservative approach to the welfare state is desirable; that its limits should be rationally questioned; that inflation, slow real economic growth, and redistribution have eroded the real income of some groups to such an extent that they will no longer support increases in transfer payment programs and are now pushing for reductions; and that there is strong pressure from electorates to avoid further increases in taxes and possibly to reduce them. Moreover, austerity budgets have been adopted in France, Belgium, the United Kingdom, Italy, the Netherlands, Denmark, and still other countries.

These events, contrasting so sharply with those of 1959-73, have raised many questions. If we continue to experience 
low real economic growth rates, as many predict we will, what effects will they have on the welfare state? Will economic policy be the principal determinant of social policies in the 1980s? In any case, what trade-offs will have to be made in social and economic policy agendas? Has the welfare state really begun to encounter limits? More important, have fundamental economic and social changes occurred in Western countries since the early 1970s?

Such questions, concerning which there is a vast store of heated and varied opinions, are easy to state but are extraordinarily difficult to analyze and answer. As Professor Peston has said,

The question of whether there has been a fundamental change in the economy or in society is deceptively simple. Methodologically very deep issues are involved. How is a fundamental change to be defined? How is it to be recognized? What have to be explained-stagflation, a lower underlying growth rate of real output, worsening industrial relations, the expansion of OPEC power, a deterioration in international economic and financial cooperation-must be separate from the explanation. One alternative is to arrive at the trivial conclusionthe cause of $\mathrm{X}$ is $\mathrm{X}$. A second is nearly as trivial; several $X s$ are very different from their former levels or rates of changes; therefore, something basic must have occurred.

The most that can be said is that what has happened is worthy of analysis and the presentation of new hypotheses which may be rather speculative in character. But it must also be added that those who take the position that nothing has happened are also in danger of trivializing the subject. ${ }^{1}$

1. Maurice Peston, "New Paths for SocioEconomic Policy," in The Welfare State in Crisis (Paris: Organization for Economic Cooperation and Development, 1981), p. 94.
In this article-hoping to avoid trivializing the subject-I present data on past trends and developments in some principal economic indicators and discuss a variety of their features. This should provide a better understanding of some of the forces shaping our present situation. Because developments in social policy in the medium term will be influenced, if not dominated, by economic forces, I next present forecasts of some of the more important economic variables for 1984 and 1985. Against this background, I identify and discuss a collection of major problems and paradoxes that will influence both social and economic policy throughout the $1980 \mathrm{~s}$, and offer some comments and conjectures for the still longer term.

\section{TRENDS AND \\ DEVELOPMENTS, $1960-83$}

Table 1 shows annual growth rates for $1960-83$ in real-inflation adjusted-gross national product (GNP), or in real gross domestic product for those countries using this measure. It is interesting to compare the annual averages for 1960-73 with those for 1975-81. The latter, for individual countries and for groups of countries such as the European Economic Community (EEC), are in most cases less than half the corresponding averages for 1960-73. Although Japan has the highest average growth for 1975-81, this figure is also less than half its average for the earlier period. Similar declines have been experienced by the 24 Organization for Economic Cooperation and Development (OECD) countries - which include developed as well as less developed nations. Nor did the Communist countries escape a similar decline across the two periods: the USSR average growth rate also dropped by more than 50 
percent, as did that for the other Eastern European countries. The data for 1983-a recovery year-appear more favorable, especially for the United States; the United States began a recovery in 1983 that turned out by mid1984 to be the strongest recovery since 1949. The improved rates in 1983 for other Western countries, however, are still substantially below their corresponding averages for 1960-73.

The similarities in the decline of average rates across the two periods are a striking phenomenon that has received little attention in published studies of real economic growth during this period. When one considers that the nations shown in Table 1 differ markedly from one another in level of GNP, in economic structure, in political system, and in cultural background and heritage, the similarity in decline appears all the more remarkable. These declines in real GNP growth rate coincide with and probably reflect worldwide declines in productivity, also a commonly shared phenomenon, which have been discussed by many researchers. ${ }^{2}$

While real economic growth rates were declining in the 1970 s, unemployment rates were increasing in many countries, as indicated in Table 2. These data, incidentally, have been adjusted in an attempt to make them more comparable across countries. Definitions and calculations of unemployment and employment vary across countries, and data are often compiled from national surveys that are taken at different times

2. One example is J. Kendrick, "International Comparisons of Recent Productivity Trends," in W. Fellner, ed., Essays in Contemporary Problems, Demand, Productivity, and Population, 1981-82 ed. (Washington, DC: American Enterprise Institute for Public Policy Research, 1981).

TABLE 1

ANNUAL GROWTH RATES IN REAL GROSS NATIONAL PRODUCT (Percentage)

\begin{tabular}{|c|c|c|c|c|c|c|c|c|}
\hline Country & $\begin{array}{c}1960-73 \\
\text { Annual } \\
\text { Average } \\
\text { (1) }\end{array}$ & $\begin{array}{c}1975-81 \\
\text { Annual } \\
\text { Average } \\
\text { (2) }\end{array}$ & $\begin{array}{c}1978 \\
(3)\end{array}$ & $\begin{array}{c}1979 \\
(4)\end{array}$ & $\begin{array}{c}1980 \\
(5)\end{array}$ & $\begin{array}{c}1981 \\
(6)\end{array}$ & $\begin{array}{c}1982 \\
(7)\end{array}$ & $\begin{array}{c}1983^{*} \\
(8)\end{array}$ \\
\hline United States & 4.1 & 2.7 & 4.8 & 2.8 & -0.4 & 1.9 & -1.7 & 4.8 \\
\hline France $^{\dagger}$ & 5.8 & 2.5 & 3.7 & 3.3 & 1.1 & 0.2 & 1.5 & 0.5 \\
\hline West Germany & 4.7 & 2.2 & 3.6 & 4.1 & 1.9 & 0.2 & -1.2 & 1.2 \\
\hline Italy ${ }^{\dagger}$ & 5.2 & 2.1 & 2.7 & 4.9 & 3.9 & -0.1 & -0.3 & -1.5 \\
\hline United Kingdom ${ }^{\dagger}$ & 3.1 & 0.9 & 3.3 & 1.6 & -2.0 & -2.0 & 0.5 & 2.5 \\
\hline Japan & 10.4 & 4.4 & 5.1 & 5.1 & 4.4 & 3.2 & 2.5 & 2.0 \\
\hline Canada & 5.6 & 2.6 & 3.7 & 3.2 & 0.5 & 3.8 & -5.0 & 3.8 \\
\hline USSR & 5.2 & 2.3 & 3.4 & 0.4 & 1.7 & 2.2 & 2.2 & 3.6 \\
\hline Eastern Europe & 4.1 & 1.8 & 3.0 & 1.0 & 0.0 & -0.9 & -0.2 & 1.0 \\
\hline $\mathrm{EEC}^{\ddagger}$ & 4.7 & 1.9 & 3.1 & 3.1 & 1.3 & -0.4 & 0.4 & 1.0 \\
\hline
\end{tabular}

SOURCES: Cols. 1, 2, and 3 from Economic Report of the President, 1983 (Washington, DC: Government Printing Office, 1983), tab. B-109, p. 285; cols. 4-8 from Economic Report of the President, 1984 (Washington, DC: Government Printing Office, 1984), tab. B-107, p. 341.

* Data for 1983 are preliminary estimates.

†Figures for France, the United Kingdom, and Italy are gross domestic product.

F"EEC" denotes the European Economic Community, which consists of Belgium, Denmark, West Germany, Greece, France, Ireland, Italy, Luxembourg, Netherlands, and the United Kingdom. 
of the year using different sample designs.

All countries shown have experienced sharp increases in unemployment rates since 1967 as the demand for labor has failed to keep pace with increases in the labor force. There is a strong tendency for real wages to continue to rise in Western countries in tandem with mounting unemployment. This, and the large indirect taxes associated with the use of labor in these countries, appear to have induced business to substitute capital for labor. Comparing 1968 with 1983, unemployment rose in the United States from 3.5 percent to 9.5 percent; in France from 2.6 percent to 8.1 percent; in the United Kingdom from 3.2 percent to 13.2 percent; and in the EEC countries, from 3.0 percent to 10.1 percent. Japan consistently had the lowest unemployment rate among those shown, but its rate for $1983-2.6$ percent-is more than twice that of 1968 .

Discussions of problems of unemployment are often stated in terms of the unemployment rate, but it is also informative to consider the volume or level of employment in various countries because a given rise in unemployment rate obviously has one impact if total employment is rising and a different impact if total employment is falling or is rising by only a small amount.

Table 3 shows total civilian employment in selected countries. Comparing data for 1972 and 1981 , we see that total employment declined in Belgium, West Germany, and the United Kingdom and grew only by small amounts in Denmark, France, and in the 10 EEC countries. Over the same period, total employment in the United States grew by 22 percent and in Japan by 8.9 percent. The United States figure is interesting. Although U.S. unemployment rates were high, the population had also been growing over the period and the U.S. economy, despite its many problems since 1973 , was able to absorb about 18 million persons into its labor force. This

TABLE 2

STANDARDIZED UNEMPLOYMENT RATES IN SELECTED COUNTRIES

(Percentage of Total Labor Force)

\begin{tabular}{lrrrrrrrr}
\hline Country & 1968 & 1970 & 1975 & 1980 & 1981 & 1982 & 1983 & $1984.1^{*}$ \\
\hline United States & 3.5 & 4.8 & 8.3 & 7.0 & 7.5 & 9.5 & 9.5 & 7.8 \\
France & 2.6 & 2.4 & 4.1 & 6.3 & 7.3 & 8.0 & 8.1 & 8.7 \\
West Germany & 1.5 & 0.8 & 3.6 & 3.0 & 4.4 & 6.1 & 7.5 & 7.3 \\
Italy & 5.6 & 5.3 & 5.8 & 7.4 & 8.3 & 8.9 & 9.7 & NR \\
United Kingdom & 3.2 & 3.1 & 4.6 & 6.9 & 10.6 & 12.3 & 13.2 & 13.3 \\
Japan & 1.2 & 1.1 & 1.9 & 2.0 & 2.2 & 2.4 & 2.6 & 2.7 \\
Canada & 4.4 & 5.6 & 6.9 & 7.4 & 7.5 & 10.9 & 11.8 & 11.3 \\
Belgium & 3.1 & 2.1 & 5.1 & 9.0 & 11.1 & 13.1 & 14.5 & 15.0 \\
Netherlands & 1.5 & 1.0 & 5.2 & 6.0 & 8.6 & 11.4 & 13.7 & 14.0 \\
Sweden & 2.2 & 1.5 & 1.6 & 2.0 & 2.5 & 3.1 & 3.5 & 3.2 \\
EEC & 3.0 & 2.7 & 4.5 & 6.0 & 7.8 & 9.1 & 10.1 & NR \\
\hline
\end{tabular}

SOURCE: OECD Economic Outlook, 35:163 (July 1984).

NOTES: Data are standardized by OECD to try to account for changes in employment and unemployment definition and calculations across countries. Data for 1967-83 are annual averages. NR denotes not recorded in source cited.

*"1984.l" denotes data for the first quarter of 1984. 
number is about twice the total amount of unemployment in the 10 EEC countries in 1981.

The problem of high unemployment rates and negative changes or small increases in total employment has many features. One is the spreading problem of youth unemployment in Western nations, especially for young women. This is exacerbated by a significant increase in labor force participation rates for women-that is, not only are more women entering the labor force than in the past, but a larger proportion is seeking entry into the labor force. There is much evidence that the incidence of unemployment has come to be relatively heavy upon young persons and particularly upon women. ${ }^{3}$

3. Space limitations prevent further discussion of these and related problems; for further discussion of unemployment and its age and sex composition in Western European countries, see W. A. Spivey, Economic Policies in France 19761981: The Barre Program in a West European Perspective (Ann Arbor: University of Michigan, Graduate School of Business Administration, Division of Research, 1982); C. Sorrentino,
In any discussion of social and economic policy the question of the size of the government relative to the size of the entire economy is of considerable importance. Size is related to questions of limits on the welfare state in the view of many commentators. Various measurement schemes for determining government size are possible and all have flaws. A standard approach to its calibration is to express total current outlays of government as a percentage of GNP; another is to calculate total current disbursements of government as a percentage of GNP. Still another measure, preferred by some, would be to express either government outlays or disbursements as a percentage of what in the

\footnotetext{
"Youth Unemployment: An International Perspective," Monthly Labor Review, 104:1-13 (July 1981); Organization for Economic Cooperation and Development (OECD), Youth Unemployment: The Causes and Consequences (Paris: OECD, 1980); idem, The Challenge of Unemployment: A Report to Labor Ministers (Paris: OECD, 1982); idem, The Unemployment of Women in OECD Countries (Paris: OECD, 1984).
}

TABLE 3

TOTAL CIVILIAN EMPLOYMENT IN SELECTED COUNTRIES (Thousands)

\begin{tabular}{|c|c|c|c|c|c|}
\hline Country & 1972 & 1975 & 1980 & 1981 & $\begin{array}{c}\text { Percentage } \\
\text { Change } \\
1972-81\end{array}$ \\
\hline Belgium & 3,697 & 3,747 & 3,751 & 3,669 & -0.76 \\
\hline Denmark & 2,355 & 2,332 & 2,460 & 2,431 & 3.23 \\
\hline West Germany & 26,125 & 24,798 & 25,302 & 25,145 & -3.75 \\
\hline France & 20,552 & 20,714 & 21,127 & 20,965 & 2.01 \\
\hline Italy & 18,875 & 19,594 & 20,572 & 20,672 & 9.52 \\
\hline Luxembourg & 147 & 156 & 159 & 160 & 8.84 \\
\hline Netherlands & 4,623 & 4,640 & 4,932 & 4,922 & 6.47 \\
\hline United Kingdom & 24,019 & 24,647 & 24,367 & 23,054 & -4.02 \\
\hline United States & 82,153 & 85,846 & 99,303 & 100,397 & 22.21 \\
\hline Japan & 51,260 & 52,230 & 55,360 & 55,810 & 8.88 \\
\hline EEC & 104,593 & 104,887 & 107,174 & 105,521 & 0.89 \\
\hline
\end{tabular}

SOURCE: Statistical Office of the European Communities, Eurostat Review 1972-1981 (Luxembourg: Statistical Office of the European Communities, 1981), p. 130. 
United States is called net national product-GNP less capital consumption allowances or the amount spent to replace used-up capital goods. Net national product thus provides an estimate of the total sales value of goods and services available for a nation's consumption and for adding to its stock of capital equipment. Unfortunately, net national product data are not as comparable across countries as GNP, so we present data on total outlays of government as a percentage of GNP, as are shown in Table $4 .^{4}$

Sweden had the largest percentage in 1982-67.3 percent; this is also the largest for any country shown in the OECD source data. Japan's percentage for 1982 is the smallest shown -34.5 percent-but its percentage for 1982 is nearly twice its 1962 estimate. Most

4. These and related issues are discussed in G. W. Nutter, Growth of Government in the West (Washington, DC: American Enterprise Institute for Public Policy Research, 1978). countries have experienced substantial increases from 1962 to 1982: the figure for Sweden and Denmark has more than doubled; Belgium's has increased 86 percent; that for the Netherlands, 79 percent; and that for the 10 EEC nations, 50 percent. Although there is no agreement about what a large percentage is, the percentages for individual West European countries shown appear to be large, as is the figure for all the 10 EEC countries.

\section{SOME FORECASTS FOR THE NEAR TERM, 1984-85}

The most recent OECD forecasts of real economic growth, which were published in midyear 1984, are given in Table 5 for selected Western nations. With the exception of the United States, Japan, and Canada for 1984, relatively modest growth rates are forecast for 1984 and for most of the countries shown in 1985. To put it another way, only in these three countries is a better-

TABLE 4

TOTAL CURRENT OUTLAYS OF GOVERNMENT AS A PERCENTAGE OF GROSS NATIONAL PRODUCT

\begin{tabular}{llllllll}
\hline \hline Country & 1962 & 1965 & 1970 & 1975 & 1980 & 1981 & 1982 \\
\hline United States & 28.8 & 27.9 & 32.4 & 35.6 & 35.0 & 35.3 & 37.6 \\
France* $_{\text {West Germany }}$ & 37.0 & 38.4 & 38.9 & 43.5 & 46.4 & 49.2 & 50.7 \\
Italy* & 35.6 & 36.7 & 38.6 & 48.9 & 48.3 & 49.3 & 49.5 \\
United Kingdom* & 30.5 & 34.3 & 34.2 & 43.2 & 46.1 & 51.2 & 53.7 \\
Japan & 34.2 & 36.4 & 39.2 & 46.6 & 45.4 & 48.0 & 47.4 \\
Canada & 19.0 & 20.0 & 19.3 & 27.3 & 32.4 & 34.3 & 34.5 \\
Belgium & 30.0 & 29.1 & 35.7 & 40.8 & 41.0 & 41.5 & 45.8 \\
Denmark & 30.5 & 32.3 & 36.5 & 44.5 & 51.1 & 55.6 & 56.6 \\
Sweden & 28.1 & 29.9 & 40.2 & 48.2 & 56.2 & 59.5 & 60.7 \\
Netherlands & 32.4 & 36.1 & 43.7 & 49.4 & 62.1 & 65.3 & 67.3 \\
EEC & 35.6 & 38.7 & 46.0 & 56.6 & 59.5 & 61.1 & 63.7 \\
& 34.2 & 36.2 & 38.2 & 46.3 & 47.8 & 50.3 & 51.3 \\
\hline
\end{tabular}

SOURCE: OECD Economic Outlook, 35:159 (July 1984).

NOTE: Total current outlays of government consist mainly of total current disbursements of government plus gross government capital formation.

* Gross domestic product is used for France, the United Kingdom, and Italy. 
than-moderate recovery being forecast. Inflation rates in all the countries shown in Table 5 have been moderating, but differentials in inflation rates among these countries have remained relatively large, posing continuing difficulties of adjustment in the international economy. Thus it appears that the relatively low rates of real growth experienced since 1973 will continue at least into the mid-1980s.

The OECD report also provided forecasts of employment and unemployment for selected countries. Table 6 shows 1982 and 1983 data and forecasts of annual percentage changes in total employment for 1984 and 1985. The European countries shown are expected to have very small increases in employment through 1985, and these gloomy prognostications follow two years of annual declines in total employment. Other studies, carried out in various
European countries, have produced similar forecasts for real economic growth, employment, and unemployment. ${ }^{5}$

Forecasts of European unemployment rates are even gloomier. Most nations are expected to have high unemployment rates, with Belgium and the Netherlands having very high predicted rates: approximately 15 percent or higher. Because all these countries have extensive unemployment assistance programs and related benefits, these forecasts, should they turn out to be accurate, suggest that these countries will experience substantial problems beyond the middle of the decade. The level of total unemployment for the OECD Eu-

5. See, for example, International Monetary Fund, World Economic Outlook (Washington, DC: International Monetary Fund, 1983), and for France, F. Eymard-Duvernay, "Combien d'actifs d'ici l'an 2000?" Economie et statistique, vol. 115 (Oct. 1979).

TABLE 5

FORECASTS OF ANNUAL GROWTH RATES OF REAL GROSS NATIONAL PRODUCT IN SELECTED COUNTRIES (Percentage)

\begin{tabular}{|c|c|c|c|c|c|}
\hline Country & $\begin{array}{c}\text { Average, } \\
1971-81 \\
\text { (1) }\end{array}$ & $\begin{array}{c}1982 \\
(2)\end{array}$ & $\begin{array}{c}1983 \\
(3)\end{array}$ & $\begin{array}{c}1984 \\
(4)\end{array}$ & $\begin{array}{c}1985 \\
(5)\end{array}$ \\
\hline United States & 2.8 & -1.7 & 3.4 & 6.0 & 2.5 \\
\hline France* & 3.1 & 1.7 & 0.7 & 1.2 & 1.8 \\
\hline West Germany & 2.5 & -1.1 & 1.3 & 3.0 & 2.8 \\
\hline Italy* & 2.9 & -0.3 & -1.2 & 2.2 & 2.2 \\
\hline United Kingdom* & 1.4 & 1.2 & 3.1 & 2.5 & 2.2 \\
\hline Japan & 4.8 & 3.0 & 3.0 & 4.8 & 3.8 \\
\hline Canada & 3.7 & -4.8 & 3.0 & 4.5 & 3.0 \\
\hline Belgium & 2.7 & -0.1 & 0.5 & 1.5 & 2.0 \\
\hline Denmark & 2.1 & 3.1 & 2.5 & 2.8 & 2.8 \\
\hline Sweden & 1.8 & -0.1 & 2.3 & 3.8 & 2.5 \\
\hline Netherlands & 2.4 & -1.4 & 1.0 & 1.5 & 1.5 \\
\hline EEC & 2.5 & 0.4 & 1.1 & 2.2 & 2.2 \\
\hline
\end{tabular}

SOURCE: For data in cols. 1 and 2, OECD Economic Out/ook, 33: 25, 26 (July 1983); for cols. 3-5, OECD Economic Outlook, 35:18, 19 (July 1984).

NOTES: Latest year for which data are available is the year 1981, so figures given for 1982 85 are forecasts. Estimates for 1983 and 1984 are rounded to one decimal place.

*Gross domestic product is used for France, the United Kingdom, and Italy. 
ropean countries is forecast to be nearly 20 million persons by 1985 - a disturbingly large figure. These forecasts, coupled with the expectations of modest real economic growth for all of the countries shown, if they are realized, will pose sustained challenges for both social and economic policies in the 1980s. They contribute considerable fuel to the arguments about limiting welfare state expenditures.

A final point should be made that may partially lighten the dark skies of the employment and unemployment forecasts: predictions from a variety of sources call for declining inflation in most Western countries and some moderation in unit labor cost increases in manufacturing. However, sharp inflation rate differentials between countries are also forecast for the next two years, which will have continued adverse effects upon the international economy.

\section{PROBLEMS IN \\ ECONOMIC AND SOCIAL POLICIES OF WELFARE STATES}

We now turn to a consideration of major problems facing welfare states in the 1980s, as well as some of the paradoxes generated by attempts to deal with these problems.

\section{Lagging private investment and capital accumulation}

A slowdown has occurred in private investment as private savings have become increasingly absorbed by the public sector and by investment in housing and consumer durable goods, the latter two outlets becoming more attractive as inflation continued to rise and expectations of still further increases strengthened. The total supply of private savings, and whether it will increase in the years ahead, are also critical variables because, by definition, total savings equal total investment, ex post. Total savings can also be separated into public and private savings, and if the former is negative, as is the case when governments incur deficits, the flow of total savings available for private investment is necessarily diminished.

Governments in the West-as well as in Japan-are currently incurring deficits and it appears that they will do so for at least several more years. Thus the savings-investment relationship will remain a problem in these countries. The continued fall in rates of return on investment during the 1970s has had a striking influence upon the demand side of investment in major Western countries. An OECD study found that re-

TABLE 6

FORECASTED CHANGES IN TOTAL EMPLOYMENT FOR SELECTED COUNTRIES (Annual Percentage Changes from Previous Year)

\begin{tabular}{lrrrr}
\hline Country & 1982 & 1983 & $1984^{*}$ & $1985^{*}$ \\
\hline United States & -0.90 & 1.30 & 4.00 & 2.00 \\
France & -0.10 & -0.90 & -1.00 & -0.50 \\
West Germany & -1.80 & -1.70 & 0.25 & 0.50 \\
Italy & -0.40 & 0.10 & 0.00 & 0.25 \\
United Kingdom & -1.70 & -0.50 & 1.00 & 0.75 \\
Japan & 1.00 & 1.70 & 1.00 & 1.25 \\
Canada & -3.20 & 0.70 & 3.00 & 2.00 \\
\end{tabular}

SOURCE: OECD Economic Outlook, $35: 41$ (July 1984).

*Figures for 1984 and 1985 are forecasts. 
alized rates of return, estimated using the ratio of gross operating surplus to gross capital stock, fell in six countries-the United States, Japan, West Germany, France, the United Kingdom, and Canada-from 1974 to 1981 and the downward trends in these rates in Canada, West Germany, and the United Kingdom can be traced back at least to the 1950 s. $^{6}$

Depressed pictures of profits and rates of return on investment have also emerged from national studies. In 1982, nonfinancial corporate profits in the United States-adjusted for inventory profits and depreciation-yielded the lowest rate of return on both gross and net capital stock in the post-World War II period; rates of return in Canada fell to their lowest levels since the 1930s, and gross profit shares in France dropped to depths not seen for 20 years. ${ }^{7}$

Reviving private investment is seen by many analysts as a key element in generating a sustained recovery in the world economy in the 1980s. Expansion in industrial countries usually spills over into the developing countries through

\section{3).}

6. OECD Economic Outlook, 33:56-57 (July

7. Assessments of total rates of return are open to technical objections because a firm's marginal expected internal rate of return is the key element in investment decision making. This is, of course, influenced in turn by expectations about the real interest rate, but both these rates are extremely difficult to calculate for an economy and one falls back on the more easily determined total rates. The determination of the real interest rate at some moment in time - in contrast to expectations concerning its future level - is itself a complex issue, as is another important decision variable, the after-tax, real interest rate. However one may respond to the technical and important problem of profitability measurement, all studies known to me have indicated that profitability, on balance, has worsened in the major economies since the early 1970 s. trade of goods and services and private capital flows, including direct investment in these countries. As the 1983 OECD Economic Outlook noted: "while the recovery probably will not be investment-led, it needs to be investmentfed, in the sense that investment needs to strengthen relatively early, so as to become a vigorous and dynamic component of growth over the medium term." ${ }^{8}$ An increase in private investment over the present relatively low levels would require a surge in business confidence and a marked improvement in profit expectations, both of which need the spur of rising sales and favorable cost anticipations-in particular, prospects of favorable real after-tax interest rates. We also need a social and political environment that encourages the risk taking required to energize the investment process; this environment must include, obviously, improved profit expectations.

Will sufficient private investment materialize to assist a recovery in the world economy? Assessments by students of the subject vary from unfavorable to at best mildly favorable, but almost all foresee many problems and dangers, particularly with respect to continuing high real interest rates, strong international price competition, uncertainty in foreign exchange rates, and sustained fears of high inflation rates. Increases in productive investment will require allocation of resources toward investment and away from both private and public consumption. This is to an important extent a political as well as an economic problem because the question naturally arises, Whose consumption is to be foregone? The prob-

8. OECD Economic Outlook, 33:6 (July 1983). 
lem is compounded by the prospects of continuing public and total budget deficits.

After sifting through all these issues, I believe that it is unlikely that private investment will provide the needed impetus to real economic growth in the world economy; that stop-and-go conditions with respect to growth-or more precisely, go-and-stop conditions-are likely to continue in the major nations with the exception of the United States and Japan during the remainder of the $1980 \mathrm{~s}$; and that pressures on government budgets will increase.

\section{Labor markets, employment, and unemployment}

Stagnating investment together with continuing high levels of real wages, as we have seen, account for a good deal of the rise in unemployment in major nations since 1973 . Western countries have tried to lessen the magnitude of these problems but this has often, and paradoxically, contributed to their worsening. An example is provided by the way governments raise revenues to spend on unemployment and on related income maintenance programs. The revenues are largely derived from taxes on employers and on those who are employed rather than from the general revenue-this is particularly true in countries in Western Europe. This tends to raise costs for employers and to depress demands for goods and services by workers, both of which have dampening effects on aggregate demand and upon subsequent employment growth.

Efforts to deal with the youth unemployment problem have also generated paradoxes. A program often set forth by politicians, ostensibly to assist the young, is that of legal minimum wages. These have been the subject of many investigations; and although points of view differ, many studies have found that a 10 percent increase in the minimum wage reduces teenage employment by approximately 1 to 3 percent and that it also has a negative effect on young adult employment-persons aged 2024-although less than its effect on teenage employment.

Some governments have become concerned about the effects of high taxes on employment and about the possible detrimental effects of increases in the minimum wage and have passed legislation aimed specifically at remedying each. France initiated a national employment pact (pacte nationale pour l'emploi des jeunes) in 1977, extending it with second and third pacts in 1978 and 1979. The principal feature of these arrangements was to grant employers a partial and temporary exemption from paying their required social security contributions. Other nations have discussed waiving minimum wages selectively. Little is known, however, of the extent and effects of these programs on unemployment, even though their costs in budgetary terms have been considerable.

A program developed in West Germany beginning in 1973 provides another example of a measure motivated by a desire to ameliorate rising youth unemployment- but which had a paradoxical result. Its principal purpose was to encourage older workers to leave the labor force by offering early-retirement inducements. Workers with an appropriate number of years of employment could retire at age 63 , two years before the statutory retirement age, and workers aged 62 or more could retire with an actuarially reduced pension determined by various factors. The entire package was considerably more 
liberal than the early-retirement arrangements introduced in the United States some years later.

The program was originally expected to have little influence on the decisions of older workers, although if this be so, one wonders why it was regarded as likely to help young persons. In any case, the predictions related to the program turned out to be incorrect and the program has been much more costly than anticipated. It is regarded as an important component in the subsequent deficits in the German old-age pension fund. The large number of persons taking advantage of the plan contributed substantially to the rapid growth in the number of pension recipients between 1974 and 1977, and the program has turned out to be a costly attempt to deal with the problem of youth unemployment. ${ }^{9}$

The magnitude of the unemployment problem (see Tables 2 and 3), its political and institutional sensitivity and paradoxes, and the prospects for prolonged sluggish economic growth suggest that major nations will continue to struggle with unemployment issues and, unless private investment improves, will encounter only limited success in the remainder of the decade.

\section{Problems in the international economy}

A commonplace observation holds that interdependence has grown enormously in the world economy. A standard measurement of a country's dependence in the international economy is the ratio of its merchandise imports or exports to its GNP. However, ratios of

9. See Christine Cumming, "Social Security in Germany and the United Kingdom," Federal Reserve Bank of New York Quarterly Review, pp. 19-20 (Spring 1983). imports or exports to the production of goods are more informative figures because GNP includes expenditures on services-sizable in the West-most of which are not involved in international transactions, whereas services are excluded from the production of goods. Both sets of ratios for exports are shown in Table 7.

Although exports were about 7.8 percent of GNP in the United States in 1981, exports expressed as a percentage of U.S. production of goods amounted to 26.6 percent. Some writers have suggested that figures like the latter, indicating a much larger involvement in international trade than is usually acknowledged for the United States, go a good way toward explaining movements in our economy over the last five years. These writers also assert that some of our difficulties, particularly in manufacturing, are attributable to the extensive domestic impacts of international developments. The ratios of exports to total production of goods in the other countries shown also provide food for thought. With the exception of Japan, these are over 60 percent and suggest how sensitive economic policy in these countries must be to outside influences. In particular, domestic fiscal and monetary policies have to be conducted with an awareness of these issues. More will be said on this later.

We have also learned, however, particularly since 1979 , that interdependence works in a variety of directions. It can spread prosperity when the major economies of the world are expanding, but it can spread recession when these economies are contracting. ${ }^{10}$ It has also been pointed out that solutions to prob-

I0. L. B. Krause, "Perspectives, the Crisis in the World Economy," Brookings Review, p. 4 (Spring 1983). 
lems of developing countries and particularly to problems posed by their external debts depend on sustained growth in the world economy over the coming years. One author estimates that exports of the developing countries could rise by 20 to 30 percent per year should this occur, whereas further stagflation in the world economy could result in a decline of up to 10 percent in their exports and an international debt position of crisis proportions for developed and underdeveloped nations alike. ${ }^{11}$ We again see the importance of healthy rates of real economic growth in the major nations and the dangers posed by the modest growth rates predicted earlier.

Despite the growing interdependence of nations, however, international cooperation has broken down, protection-

11. Ibid., p. 5. ism is again on the rise, and international policy harmonization has steadily become more difficult to pursue, much less to achieve. Nations have struggled to find a good mix among monetary, fiscal, and foreign exchange rate policies but have not been successful. The pressures of the 1970s led many nations - notably the United States and the United Kingdom - to try to disinflate their economies through monetary policies in the 1980 s, but political problems and pressure-group action led to fiscal policies that were not harmonious with this goal. Western nations have, by and large, tended to overuse monetary policies because monetary authorities can exert more influence over monetary policies than politicians can-or willover fiscal policies. Thus it is not uncommon to see tight monetary policies and loose fiscal policies when a mix of a somewhat looser monetary policy and a

TABLE 7

RATIOS OF MERCHANDISE EXPORTS TO GROSS NATIONAL PRODUCT AND PRODUCTION OF GOODS

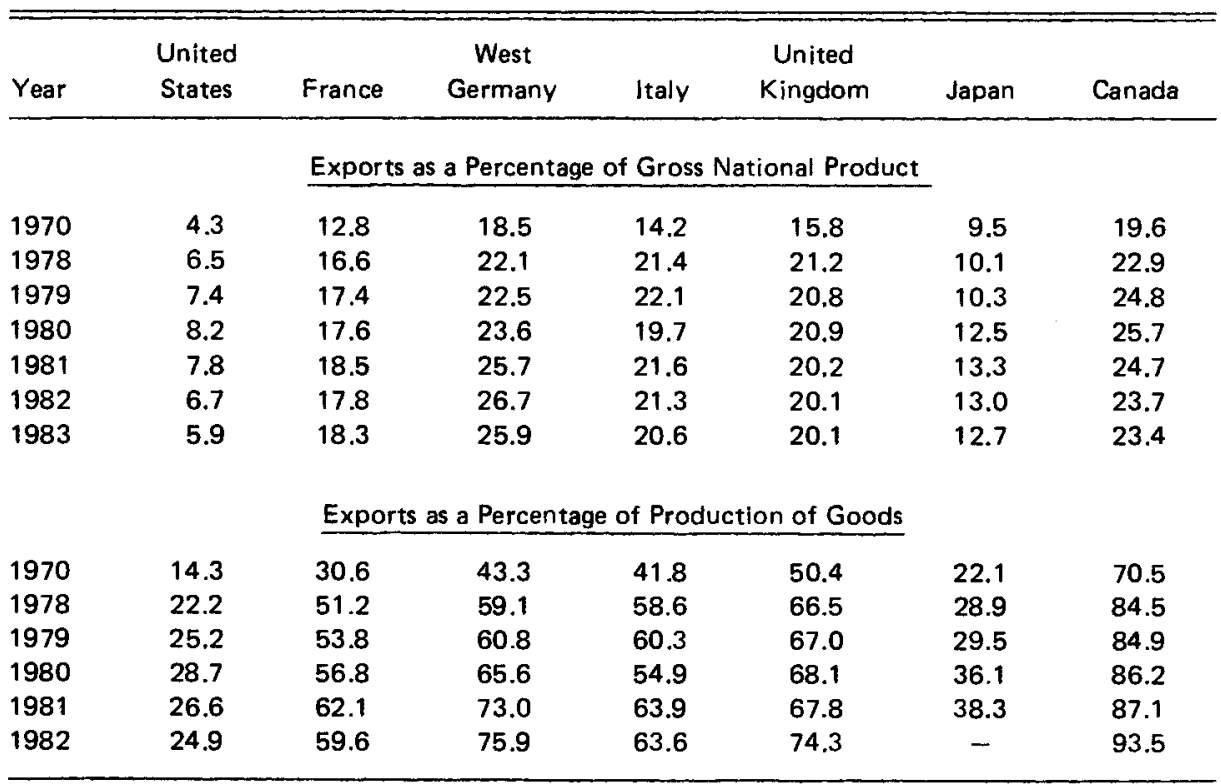

SOURCE: International Economic Indicators, p. 36 (June 1984). 
tighter fiscal policy, at least in theory, would maintain aggregate demand and possibly produce lower interest rates.

Western nations are troubled also by structural deficits in their total budgets. ${ }^{12}$ Moreover, structural deficits appear likely to grow as future spending increases are expected to exceed future rises in tax revenues-spending legislation is almost always more popular with voters than tax increases.

Countries have also struggled to stabilize or to stimulate their domestic economies with policies that have had adverse effects upon their balance of payments and foreign exchange positions. A good example is that of France, which tried domestic stimulation at a time (1981-83) when other nations were either disinflating or avoiding stimulative policies. Among the results are two devaluations of the franc in as many years, continued high inflation and interest rates and unemployment, and a decline of about 30 percent-before correcting for inflation-in France's foreign exchange reserves. By 1983 the government found it necessary to borrow money from other European nations in order to maintain membership in the European Monetary System; and in 1984 the government had to announce an austerity program, which constituted a major shift away from goals it had set in 1981 .

It appears likely that problems of mixing monetary, fiscal, and foreign exchange policies will continue to trouble Western nations, that fiscal policy will continue to be dominated by do-

12. Structural deficits are the amount by which revenues would trail outlays even at levels of relatively low unemployment and are contrasted with cyclical deficits, which are caused by transitory influences such as recession conditions that tend to disappear as recoveries take hold. mestic political considerations, and that a lion's share of the operational policy burdens will continue to be borne by monetary policy.

\section{Unfavorable demographics and the \\ imbalance between social program \\ benefits and contributions}

Many writers have discussed various unfavorable aspects of population developments in Western nations, chiefly the aging of populations and an unsatisfactory distribution of persons in the labor force and those dependent on the social security system. In France in 1980, for example, it was estimated that persons who were economically active-about 40 percent of the population-contributed to the support of the remaining 60 percent, who were inactive. Another measure of aging is provided by the ratio of workers to nonworkers over 65 years of age; because nonworkers appear in the denominator of this ratio, a smaller ratio usually indicates a larger number of nonworkers over 65 . Table 8 gives data for selected years for three countries as well as forecasts for the year 1990.

The imbalance between social program benefits and contributions has been assessed in a variety of ways, many of which employ differing assumptions and thus produce differing results. At least three recent studies have questioned the standard portrayal of social security financing and the conventional actuarial estimation procedures used in them. They have asserted that a fundamental problem currently exists and will continue to exist for many years to come because retirees can expect to receive benefits far in excess of lifetime contributions plus interest. ${ }^{13}$

13. J. R. Capra, P. D. Skaperdas, and R. M. Kubarych, "Social Security: An Analysis of Its 
One way to assess this problem is to develop estimates for a hypothetical but representative individual over a long time period and to make comparisons across various countries. In the study by Cumming, which updates data and results of the study by Capra, Skaperdas, and Kubarych, the individual is taken to be a 65 -year-old, single male with average lifetime earnings. A ratio of the discounted present value of expected benefits to lifetime employer-employee contributions-plus interest -is estimated for the United States, Great Britain, and West Germany. The results are shown in Figure 1.

When the ratio is equal to 1.0 , the discounted present value of benefits equals accumulated contributions plus interest; when the ratio exceeds 1.0 , the discounted present value exceeds accumulated benefits; and when the ratio is less than 1.0, the opposite is the case. A reference line corresponding to $1.0-$ the dashed line--is indicated in Figure

Problems," Federal Reserve Bank of New York Quarterly Review, pp. 1-17 (Autumn 1982); Cumming, "Social Security in Germany"; and Klaus-Peter Koppelmann, "Intertemporal Income Distribution in the Statutory Pension Insurance of West Germany," in Studies in Applied Economics and Statistics (Goettingen: van den Hoech and Ruprecht, 1979), 8:127-39.
1. Using this measure, which is only one approximation of a complex relationship that is difficult to assess, one can make a rough inference-by interpolating between appropriate data pointsthat the present discounted value of benefits will exceed the lifetime contributions plus interest in West Germany until about 1998, in Great Britain until about 2011, and in the United States until about 2015 .

The authors of the studies done in the United States use these and other analyses to conclude that social security funding in the countries examined faces not only a short-run crisis, as many policymakers have been assuming during the last 10 years, but more important a long-run problem that will persist into the next century.

\section{SOME CONCLUDING COMMENTS}

In the light of the problems and paradoxes we have considered, what is likely to occur in the remainder of the decade with respect to major economic forces and what will be the impact of these on the welfare state? Drawing together the various findings and forecasts presented earlier to form what can only be called my surmises, I believe that most West European nations will experience at best a modest economic re-

TABLE 8

RATIO OF WORKERS TO NONWORKERS OVER AGE 65, 1950-90

\begin{tabular}{lllllll}
\hline Country & 1950 & 1960 & 1970 & 1980 & 1990 & $\begin{array}{c}\text { Percentage } \\
\text { Change } \\
1950-90\end{array}$ \\
\hline United States & 7.15 & 5.51 & 5.15 & 4.95 & 4.70 & -34.3 \\
West Germany & 5.95 & 5.09 & 3.71 & 3.46 & 3.87 & -34.9 \\
France & 5.22 & 4.56 & 4.05 & 3.66 & 3.73 & -28.5 \\
\hline
\end{tabular}

SOURCE: Christine Cumming, "Social Security in Germany and the United Kingdom," Federal Reserve Bank of New York Quarterly Review, p. 17 (Spring 1983). 
FIGURE 1

RATIO OF DISCOUNTED PRESENT VALUE OF BENEFITS TO LIFETIME

CONTRIBUTIONS PLUS INTEREST

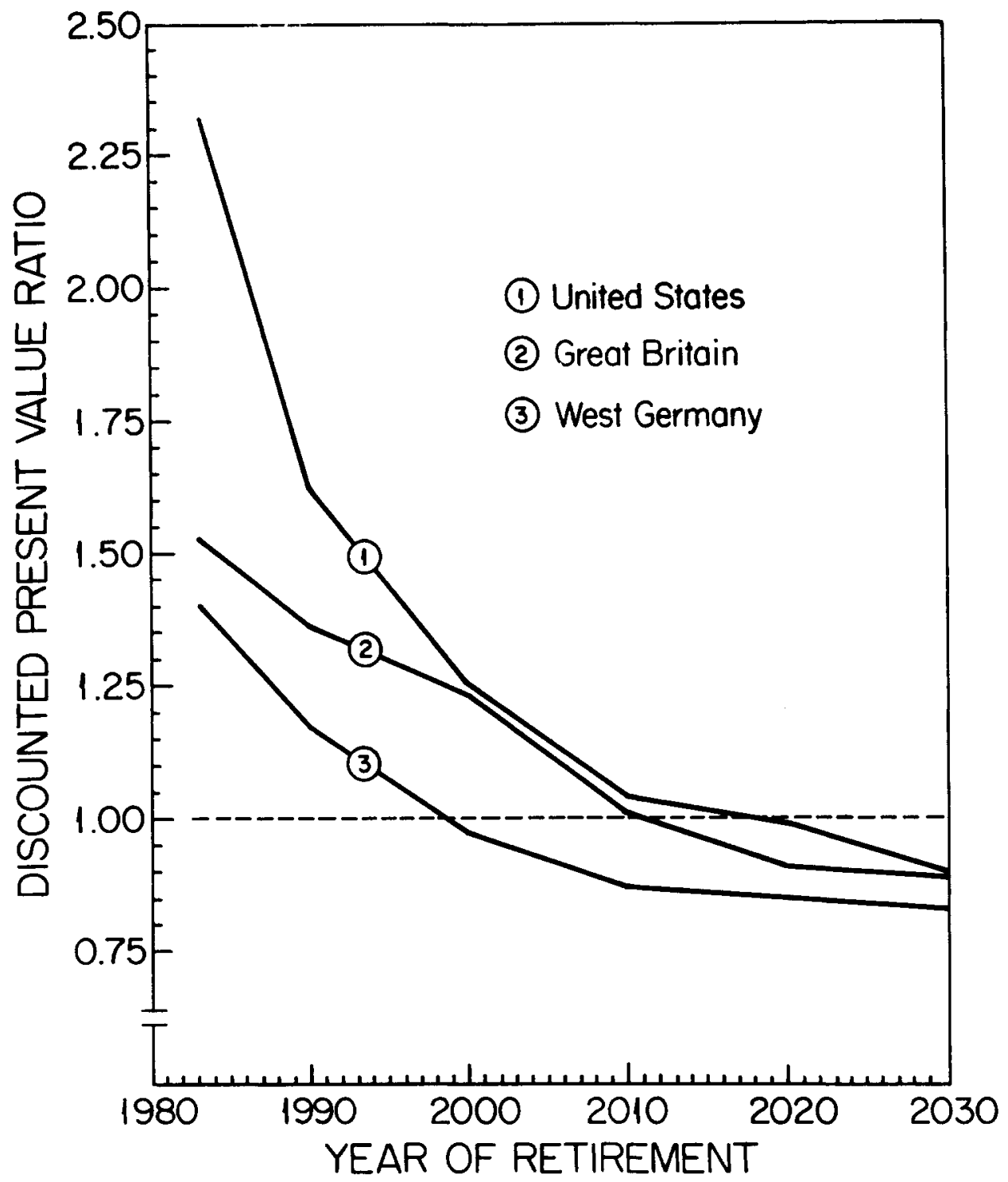

SOURCE: Telephone interview with Christine Cumming of the Federal Reserve Bank of New York, 20 Aug. 1984. 
covery for the remainder of the decade. The United States and Japan - and possibly Canada-are likely to do better than this. Beyond the 1980s, we can expect persistent high levels of unemployment and low rates of growth of total employment in West European countries; these countries appear unlikely to generate, either economically or politically, adequate incentives for significant growth in private investment, so economic growth rates will not rise to the levels associated with the expansion of the welfare state in the period 195973. Moreover, the relatively high unemployment levels and the aging of the population will continue to exert pressures on the financing of social security programs so that, coupled with low real economic growth rates, a crisis atmosphere in the funding of social programs will continue well into the final decade of this century and possibly beyond.

Against this background one can expect to encounter more discussion of the limits of the welfare state, continued or increasing austerity in government budgets, continued agonizing over the interface between economic and social policy, and a world in which economic factors have far more influence over social policy than in the period 1959-73. This will lead to still more difficult challenges for policymakers and to yet more illustrations of the truth of Max Weber's statement that effective policy requires "a strong, slow drilling through hard boards with both passion and cool judgment. ${ }^{.14}$ Finally, reactions, evasions, and outright resistance to unpopular economic and social policies will probably continue to grow beyond their already substantial levels, and assumptions of the passive reactions of individuals will have to be modified in our theories as well as in their application if they are to help us deal more effectively with the world in which we live.

14. Max Weber, "Politik als Beruf" (Oct. 1919) in Gesammelte politische Schriften, 3rd rev. enlarged ed., ed. Johannes Wineklemann (Tübingen: J.C.B. Mohr [Paul Sieback], 1971), p. 560. 